\title{
Threats to the evergreen forests of southern Malawi
}

\author{
F. Dowsett-Lemaire and R. J. Dowsett
}

Malawi has a large number of isolated highland forests on either side of the Rift Valley. While those in the north do not at present suffer from serious degradation, in the south several have been much encroached upon for fuel wood and land for cultivation. As a result localized birds, reptiles, butterflies and plant species are threatened. In a two-year exploration of the evergreen forests of the country conducted for the Forestry Department, the authors surveyed the distribution and status of the flora and fauna, and identified threats to the survival of the rarer taxa.

Malawi is a small country of enchanting and varied landscapes, with the greatest number (more than 40) of isolated mountain or hill forests in south-central Africa. Only one area, the Nyika Plateau in the north, is protected comprehensively within a national park. Most other forest patches are included in forest reserves, but their protection status depends more on local human demands for land and wood. The density of human population is particularly high south of $14^{\circ} \mathrm{S}$ and endangers the survival of several local species of wildlife and plants.

\section{The vegetation}

Most of the forested hills in southern Malawi are situated east of the Rift Valley formed by the Shire River (Figure 1) and bear mid-altitude evergreen forests (Table 1). The flora was described in part by Chapman and White (1970), but the importance of medium-altitude forests was overlooked. A more complete account of the vegetation is in progress (Dowsett-Lemaire, 1988 and unpub.). The wetter types of mid-altitude forest are dominated by $40-\mathrm{m}$ tall Newtonia buchananii trees, and constitute a community little studied and largely destroyed in the African tropics. Two of the finest examples of Newtonia forest occur on Chikala Hill and in the Ruo Gorge (Mulanje), with an interesting mixture of lowland and Afromontane elements. Those 158 on the slopes of Mt Mulanje are (or were) most extensive; 123 species of trees and woody shrubs have been recorded (Dowsett-Lemaire, 1988). There is an endemic tree Rawsonia (Dasylepis) burtt-davyi and a semi-strangling

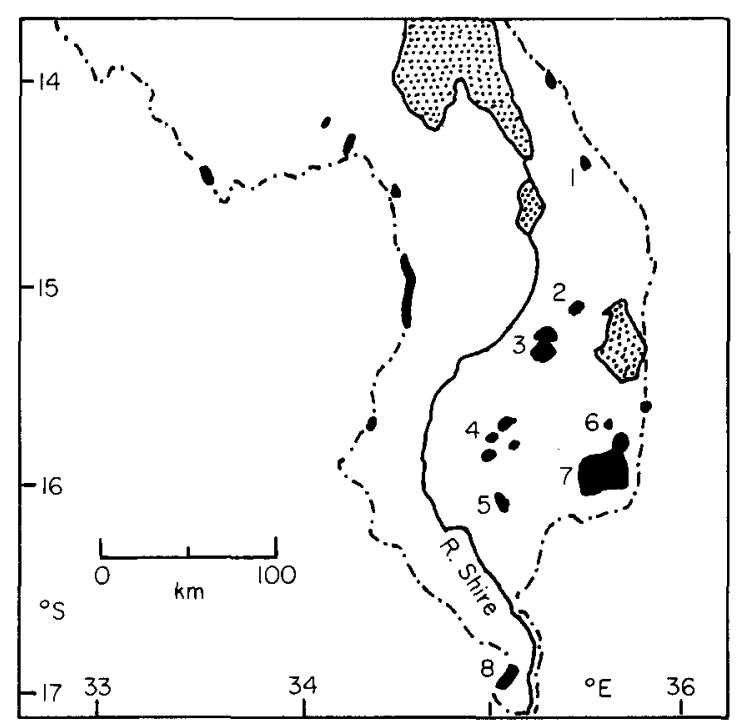

Figure 1. Map of southern Malawi showing the evergreen forests; shaded areas are lakes. Numbers refer to localities mentioned in the text: (1) Mt Mangochi; (2) Chikala Hill; (3) Mt Malosa and Mt Zomba; (4) southern Shire Highlands including Lisau and Soche; (5) Mt Thyolo; (6) Machemba Hill; (7) Mt Mulanje; (8) Malawi Hills.

Oryx Vol 22 No 3, July 1988 
Ficus so far unmatched; a new species of Tapinanthus mistletoe was recently collected from the upper Ruo Gorge. As a whole, the fern flora of the Mulanje forests is the richest in the country (over 100 species), with some Asplenium and Elaphoglossum spp. still to be named. There are two endemic Streptocarpus lithophytes (S. dolichantus and S. milanijianus) and at least one endemic orchid (Polystachya sp. 1 in la Croix et al., 1983). The small forest on Mt Soche has an apparently endemic tree in its understorey, Buxus nyasica.

At higher altitudes, above $1500-1600 \mathrm{~m}$, Afromontane forests are comparatively impoverished, but there is an interesting variant dominated by tall Widdringtonia cupressoides on $\mathrm{Mt}$ Mulanje, this cedar being at the northern limit of its range (Edwards, 1985; Dowsett-Lemaire, 1988).

\section{The wildlife}

The bird distribution in Malawi is described by Benson and Benson (1977), and the butterflies by Gifford (1965). As with the vegetation, many new distribution records were obtained during our survey. Nevertheless, several bird and butterfly species are extremely localized and their survival is threatened. The birds that are included

Table 1. Main features of the evergreen forests of southern Malawi mentioned in the text

\begin{tabular}{|c|c|c|c|}
\hline Locality & Altitude $(\mathrm{m})$ & Forest type & $\begin{array}{l}\text { Size } \\
\text { (ha)* }\end{array}$ \\
\hline MtMangochi & $1550-1700$ & Submontane & 230 \\
\hline $\begin{array}{l}\text { Chikala Hill } \\
\text { Shire Highlands. }\end{array}$ & $1300-1600$ & Mid-altitude & \\
\hline Mt Malosa & $1700-1950$ & Submontane & 730 \\
\hline Mt Zomba & $1600-1950$ & Submontane & 600 \\
\hline Lisau Saddle & $1300-1450$ & Mid-altitude & 160 \\
\hline $\begin{array}{l}\text { Mt Soche } \\
\text { Mt Thyolo }\end{array}$ & $\begin{array}{l}1300-1520 \\
1200-1450\end{array}$ & $\begin{array}{l}\text { Mid-altitude } \\
\text { Mid-altitude }\end{array}$ & $\begin{array}{r}150 \\
1000\end{array}$ \\
\hline Thyolo tea & & & \\
\hline estates & c. 1050 & Lowland & 600 \\
\hline $\begin{array}{l}\text { Machemba Hill } \\
\text { Mt Mulanje }\end{array}$ & $1150-1300$ & Lowland & \\
\hline $\begin{array}{l}\text { (incl. Mchese): } \\
\text { Lowerslopes }\end{array}$ & $600-950$ & Lowland & c. 200 \\
\hline Middle slopes & $900-1500$ & Mid-altitude & 1800 \\
\hline $\begin{array}{l}\text { Upper slopes } \\
\text { and plateaux }\end{array}$ & $\begin{array}{l}1500-1850 \\
1850-2300\end{array}$ & $\begin{array}{l}\text { Submontane } \\
\text { Montane }\end{array}$ & 5000 \\
\hline Malawi Hills & $600-900$ & Lowland & 400 \\
\hline
\end{tabular}

*Sizes are measured from aerial photographs.

Southem Malawi: evergreen forests in the African Red Data Book (Collar and Stuart, 1985) are marked with an asterisk below.

The green barbet Stactolaema olivacea occurs in Malawi, as different subspecies, only in the Misukus (extreme north) and on Mt Thyolo. It eats mostly figs, of which there is a noticeable abundance in these two forests. The distinctive subspecies on Thyolo, belcheri, is known otherwise from one mountain in adjacent Mozambique (Namuli).

The green-headed oriole Oriolus chlorocephalus* is a sparsely distributed species in southeastern Africa (Hall and Moreau, 1970). It was mentioned in five localities by Benson and Benson (1977), but in fact breeds in just two forest areas in southern Malawi: on Chikala Hill (c. 15 pairs) and Thyolo (including lowland forest on the tea estates, 40-45 pairs). Recent records on Lisau are of passage birds; there have been no acceptable records on $\mathrm{Mt}$ Soche since the 1940s; the forest on Namzadi Estate no longer exists.

The Thyolo (Cholo) alethe Alethe choloensis* was found in all the mid-altitude and submontane forests of the south (east of the Rift). It is almost endemic to Malawi, as it is otherwise known from only two mountains in adjacent Mozambique (Collar and Stuart, 1985). Overall numbers in Malawi are in the order of 1500 pairs. It is locally common in several forests, especially on Mt Thyolo (c. 200 pairs) and midaltitude Mulanje (c. 1000 pairs in 1984).

The spotted thrush Turdus fischeri* has a very localized distribution in Africa (Collar and Stuart, 1985). The Malawi endemic race belcheri is known from just four forest localities: Lisau, Soche, Mt Thyolo and the slopes of Mt Mulanje. Its overall numbers are very low-some 30 to 40 pairs.

The white-winged apalis Apalis chariessa* is presently recorded from 11 mid-altitude forests, in some of which it is common (especially Lisau). It is otherwise known from forests in Kenya (1), Tanzania (2) and Mozambique (1), and may now be extinct in Kenya. It is threatened through its prime habitat being riparian or secondary Albizia forests in the Shire Highlands, which are under heavy human pressure. Total numbers are not much above 100 pairs. 


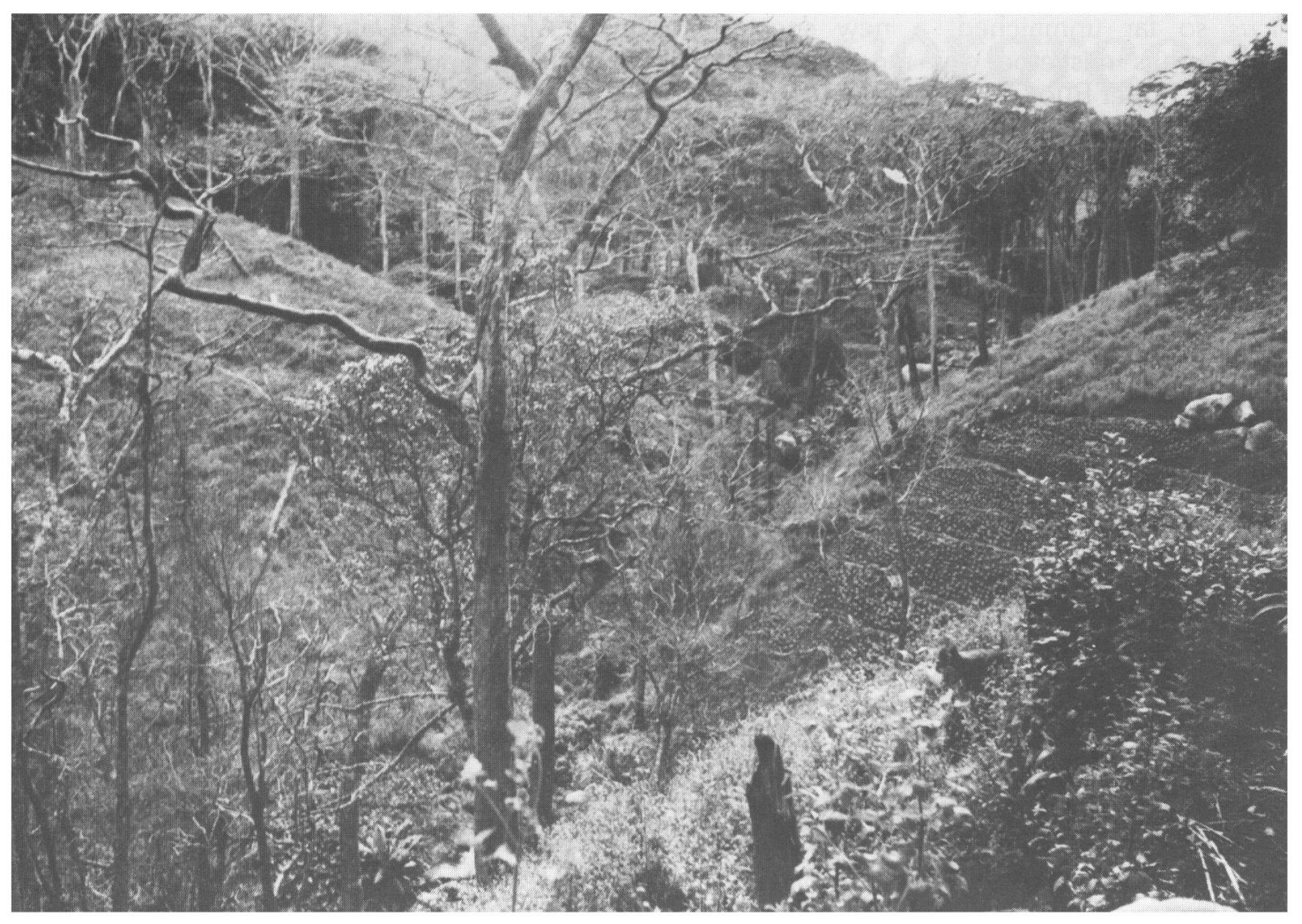

Figure 2. Large tracts of Chinsongeli Forest, Mt Mulanje, have been cleared for the planting of annual food crops.

Some 14 forest-associated butterflies are apparently endemic to Malawi, of which eight occur in the south, with three only on the slopes of Mt Mulanje: the lycaenids Alaena lamborni, A. ochracea and Baliochila woodi (Mulanje); the nymphalids Charaxes margaretae (Mulanje), $C$. martini, C. chinteche (north also). Cumothoe zombana and C. melanjae (Mulanje).

The forests are too small to contain many species of large mammals. The blue monkey Cercopithecus albogularis is still common locally, as is a forest antelope, the blue duiker Cephalophus monticola. Hunters have exterminated in places bushbucks Tragelaphus scriptus and bushpigs Potamochoerus porcus.

Among other vertebrates, an endemic chameleon Chamaeleo mlanjensis (Broadley, 1965) and an endemic subspecies of frog Arthrolepis adolfifriederici francei (Stewart, 1967) are confined to rain forest along the Ruo River on 160
Mulanje. Another chameleon Rampholeon platyceps appears endemic to the forests of southern Malawi, from Mulanje and Zomba to the Malawi Hills (Loveridge, 1953; Hargreaves, 1979).

\section{The conservation status of the evergreen forests}

All forest remnants but one (on Machemba Hill where the forest is being felled) are included in forest reserves. However, the increasing human population is placing timber and firewood supplies under severe pressure in most places. On the Mulanje slopes, forest is also cleared for subsistence cultivation: many of the estate workers have insufficient land for gardens at lower levels, and there is also an influx of squatters from war-torn Mozambique. As a result, all lowland and mid-altitude forests remaining on Mulanje are seriously threatened. For example, Chisongeli Forest, on the south-eastern slopes,

Oryx Vol 22 No 3, July 1988 


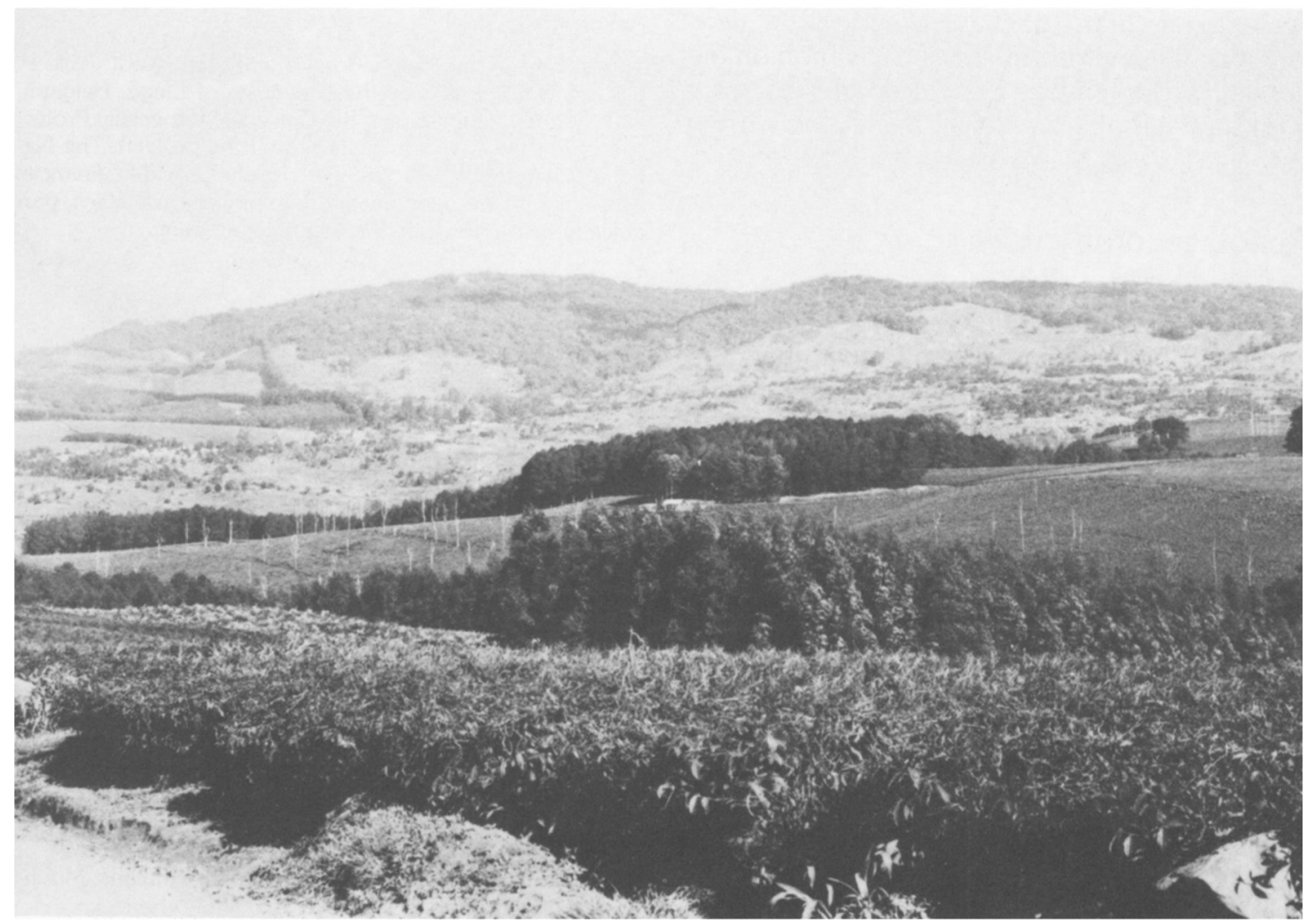

Figure 3. Mt Thyolo, with the hill forest eaten into by cultivated land; tea and Eucalyptus plantations in the foreground.

extended from 900 to $1800 \mathrm{~m}$, and aerial photographs show that it still covered $40 \mathrm{sq} \mathrm{km}$ in 1974, thus being the largest single block of forest in Malawi. Destruction has accelerated in the last few years and little forest now remains below $1500 \mathrm{~m}$ (Figure 2). The wood is wasted, and maize gardens established on steep rocky slopes are soon washed away, encouraging further felling. These Newtonia-dominated forests are not only an ecosystem of considerable scientific interest, but also provide a vital source of waterin particular for the foreign-exchange-earning tea estates extending over the plains below.

Equally disturbing is the situation on and around Mt Thyolo. The Thyolo area (1000-1400 m) lost most of its forest early this century, with the establishment of the tea estates. Some of the estates have preserved important fragments of lowland forest in stream depressions, but the forest reserve established on $\mathrm{Mt}$ Thyolo itself has Southem Malawi: evergreen forests been steadily encroached upon for gardens in the past 20 years (Figure 3).

Quite a number of the Shire Highlands forests are endangered. The most important of these from the natural history viewpoint is Soche, near Blantyre. It had been reduced in size to 150 ha by 1974; felling continues illegally and unless this is stopped at once, the city of Blantyre will lose for ever what could be an environmental education area of considerable value.

Among the larger forests that are fairly well protected are Mt Mangochi, Chikala, Malosa, Zomba and Lisau. The buffer zone of woodland around Chikala and Lisau has been extensively cut, however, and pressure on the forests will increase. The Widdringtonia forests on the high plateaux of Mulanje still suffer from felling of cedars and illegal bushfires. Burning has not ceased in recent years (contrary to the predictions of Edwards, 1985). The lack of fire-breaks 
below the lip of the plateaux is a problem, worsened by the encroachment of cultivation on the slopes. In September 1983 several fires were even lit inside the fire-break protection on the top.

\section{Action recommended}

What is needed overall is recognition of the importance of preserving as many evergreen forests as possible for water, soil and timber conservation, with particular attention being paid to the enforcement of the laws in those areas of special scientific interest. Most of these forests are relatively small, and policing them effectively initially requires an increase of forest guards, finance for which might be sought from external donors. The pressing need for timber (building poles and firewood) must also be met by the planting of more fast-growing exotic trees in areas near to large human settlements; wherever possible this should be on land that is not well forested with indigenous vegetation. Attention should also be given to a reafforestation programme using indigenous trees, although the time scale involved will mean this is of no help to forests under immediate threat. One of the ways that destruction of the forested slopes of Mulanje could be halted is by providing the tea estate workers with rations of maize meal-at present their incomes are insufficient to buy food. Otherwise illegal gardens cannot reasonably be banned.

Unfortunately, even well-planned reafforestation and other measures will not overcome the rate of forest destruction in the most populated areas (particularly the southern Shire Highlands and the lower slopes of Mulanje), and several unique forest ecosystems in southern Malawi are not likely to survive the next decade or two.

\section{Acknowledgments}

This survey of the Malawi forests was carried out while $\mathrm{F}$. D.-L. was employed by the University of Liège, Belgium, and we are very grateful to the University (especially Professor J.-C. Ruwet who fully supported the project). The National Geographic Society generously provided financial assistance. Many people were helpful to us in Malawi, particularly field staff of the Forestry Department.

\section{References}

Benson, C.W. and Benson, F.M. 1977. The Birds of Malawi. Montfort Press, Limbe.

Broadley, D.G. 1965. A new chameleon from Malawi. Arnoldia, 32, 1-3

Chapman, J.D. and White, F. 1970. The Evergreen Forests of Malawi. Commonwealth Forestry Institute, University of Oxford.

Collar, N.J. and Stuart, S.N. 1985. Threatened Birds of Africa and Related Islands. ICBP and IUCN, Cambridge.

la Croix, I., la Croix, E.A.S., la Croix, T.M., Hutson, J.A. and Johnston-Stewart, N.G.B. 1983. Malawi Orchids. Volume I. Epiphytic Orchids. National Fauna Preservation Society of Malawi, Zomba.

Dowsett-Lemaire, F. 1988. The forest vegetation of Mt Mulanje (Malawi): a floristic and chorological study along an altitudinal gradient (650-1950 m). Bull. Jard. Bot. Nat. Belg. 58, 77-107.

Edwards, I. 1985. Conservation of plants on Mulanje Mountain, Malawi. Oryx, 19, 86-90.

Gifford, D. 1965. A List of the Butterflies of Malawi. Society of Malawi, Blantyre.

Hall, B.P. and Moreau, R.E. 1970. An Atlas of Speciation in African Passerine Birds. British Museum (Natural History), London.

Hargreaves, B.J. 1979. Cautious, carnivorous clownschameleons of Malawi. Nyala 5, 32-39.

Loveridge, A. 1953. Zoological results of a fifth expedition to East Africa. III. Reptiles from Nyasaland and Tete. Bull. Mus. Comp. Zool. Harvard, 110, 141-322.

Stewart, M.M. 1967. Amphibians of Malawi. State University of New York Press, New York.

F. Dowsett-Lemaire and R.J. Dowsett, Rue de Bois de Breux 194, B-4500 Jupille, Liège, Belgium. 